\title{
Circulating tumor cells prior to initial treatment is an important prognostic factor of survival in non-small cell lung cancer: a meta-analysis and system review
}

\author{
Sha-Sha Jiang, Bo Deng*, Yong-Geng Feng, Kai Qian, Qun-You Tan and Ru-Wen Wang
}

\begin{abstract}
Background: Our study aimed to verify the prognostic value of circulating tumor cells (CTCS) prior to initial treatment on survival of non-small cell lung cancer (NSCLC) by using meta-analysis and system review of published studies.

Materials and methods: The PubMed, EMBASE and Cochrane Library were searched, respectively, to identify all studies that addressed the issues of CTCs prior to initial treatment and progression-free survival (PFS) and overall survival (OS). Finally, ten citations were included for analysis and assessment of publication bias by using review manager 5.3 statistical software and STATA 15.0.

Results: Randomized model analyzing multivariate Cox Proportional Hazards Regression indicated that higher abundance of CTCS significantly predicts poorer prognosis of lung cancer cases basing both on PFS $(Z=2.31, P=$ $0.02)$ and $O S$ of advanced cases $(Z=2.44, P=0.01)$, and systematic study aslo indicated the similar results.
\end{abstract}

Conclusion: High CTCS prior to initial treatment can predict shorter PFS and OS in NSCLC, and further studies are warranted in the future.

Keywords: Circulating tumor cells, Non-small cell lung cancer, Prognosis, Meta-analysis

\section{Background}

Circulating tumor cells (CTCs) are a variety of tumor cells which are detached from primary site, destroy the integrity of the base membrane, and enter the peripheral blood [1]. The cells have the ability to spread through blood and form distant metastasis in an appropriate microenvironment [2].

The underlying mechanism of how CTCs shed into the peripheral blood circulation is still unclear. Animal experiments showed that this process may be related to epithelial-mesenchymal transition (EMT), which enable epithelial cells to be highly invasive [3]. However, most of CTCs may develop apoptosis or be killed by immune system, leading to the survival of very few to form

\footnotetext{
* Correspondence: dengbo@tmmu.edu.cn

Department of Thoracic Surgery, Institute of Surgery Research, Daping Hospital, Army Medical University, Chongqing 400042, People's Republic of China
}

(c) The Author(s). 2019 Open Access This article is distributed under the terms of the Creative Commons Attribution 4.0 International License (http://creativecommons.org/licenses/by/4.0/), which permits unrestricted use, distribution, and reproduction in any medium, provided you give appropriate credit to the original author(s) and the source, provide a link to the Creative Commons license, and indicate if changes were made. The Creative Commons Public Domain Dedication waiver (http://creativecommons.org/publicdomain/zero/1.0/) applies to the data made available in this article, unless otherwise stated. verify the underlying clinical significance of CTCs monitoring in cancer cases.

CTCs detection is also widely used to predict prognosis of a variety of lung tumors, including small cell lung cancer, squamous cell lung carcinoma, lung adenocarcinoma and large cell lung cancer. However, the results are largely inconclusive. Higher number of CTCs before treatment and after two cycles of chemotherapy were found to be closely related to higher stage and worse prognosis of small cell lung cancer [5]. Furthermore, CTCs and CTC clusters may be potentially predictable for risk of recurrence and short survival in early nonsmall cell lung cancer patients (NSCLC) [6]. However, another study showed that CTCs before treatment had no significant relationship with the overall survival of non-small cell lung cancer patients [7]. 
This study aimed to verify the predictive power of CTCs prior to treatment on the prognosis in non-small cell lung cancer, which may be an important disease screening and guideline of the accurate treatment.

\section{Materials and methods}

\section{Data sources and searches}

Medline and manual searches were performed by Jiang SS and DB, independently and jointly to identify all publications that addressed relationship between CTCs and prognosis of non-small lung cancer. Three MESH TERMs "Lung Neoplasms", "Prognosis"and "Neoplastic Cells, Circulating" were searched in the PubMed, EMBASE and Cochrane Library database, respectively (Fig. 1).

We excluded the studies uncorrelated with NSCLC, and written in neither Chinese nor English, and case reports, reviews, and meta-analysis. Therefore, we included those studies focusing on CTCs prior to initial treatments and progression-free survival (PFS) and overall survival (OS) by using multivariate Cox Proportional Hazards Regression (multivariate COX model) with Hazard Ratio and 95\%CI. Finally, a total of 10 citations were included for analysis (Tab. 1 and Fig. 1).
Levels of evidence were evaluated according to the recommendation of the American Academy of Orthopedic Surgeons Evidence-Based Practice Committee, and a trial quality score was assessed according to the method of Jadad et al. [8]. The evaluation of CTCs as a prognostic factor was performed by analyzing the hazard ratio (HR) and their 95\% confidence interval (CI), using randomized model, due to heterogeneity among the studies. The publication bias of selected studies was assessed by means of Egger's regression test and funnel plot, and $P<0.05$ was considered the existence of publication bias. Meanwhile, Green I statistics were used to assess heterogeneity. Stratified analysis was used to identify the potential confounders leading to heterogeneity. $\mathrm{I}^{2}>50 \%$ indicated the existence of significant heterogeneity. All statistical analysis was calculated by using Review Manager 5.3 for meta-analysis and STATA 15.0 for evaluation of publication bias, respectively.

\section{Results}

Publication bias test regarding PFS and OS unveiled most studies were at the top of the inverted funnel, while very few studies were at the base, and the left and right are roughly symmetrical. Additionally, Egger's regression test

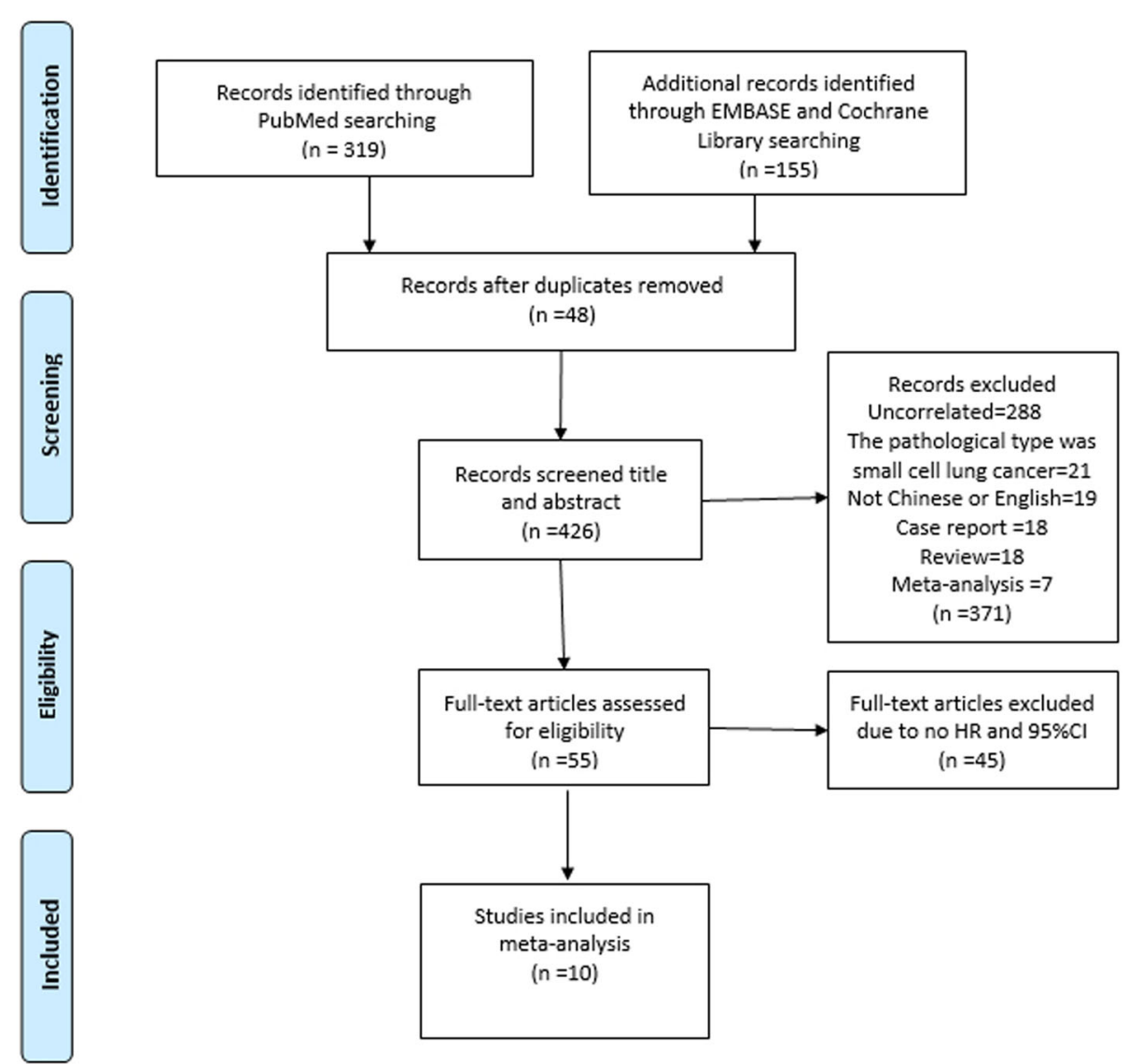

Fig. 1 Flow chart showing the flow of publications via the review process 
Table 1 Summary of the published studies included in the meta-analysis and system analysis

\begin{tabular}{|c|c|c|c|c|c|c|c|c|c|}
\hline PumlD & $\begin{array}{l}\text { Published } \\
\text { year }\end{array}$ & $\begin{array}{l}\text { Detection } \\
\text { method }\end{array}$ & $\begin{array}{l}\text { Cases } \\
(\mathrm{N})\end{array}$ & $\begin{array}{l}\text { Mean } \\
\text { age }\end{array}$ & $\begin{array}{l}\text { Tumor } \\
\text { Stage }\end{array}$ & Pathological diagnosis & Cutoff & Biomarker & $\begin{array}{l}\text { Patients with } \\
\text { high level of } \\
\text { CTCs (n) }\end{array}$ \\
\hline $29,110,843$ & 2017 & $\begin{array}{l}\text { size-based } \\
\text { microfilter } \\
\text { assay }\end{array}$ & 40 & 67 & $|/||/|||$ & Adenocarcinoma & $\geq 1 / 7.5 \mathrm{~mL}$ & N.A. & 15 \\
\hline $28,919,743$ & 2017 & NanoVelcro & 143 & $(-)$ & $|/||/||| / \mid V$ & Adenocarcinoma & $\geq 1 / 1 \mathrm{~mL}$ & CK+/CD45-/DAPI+, & 37 \\
\hline $28,633,480$ & 2017 & Cellsearch & 125 & 61 & $|/||/|||$ & $\begin{array}{l}\text { Squamous/ Adenocarcinoma/ } \\
\text { Others }\end{array}$ & $\geq 5 / 7.5 \mathrm{~mL}$ & $\mathrm{CK}+/ \mathrm{CD} 45-/ \mathrm{DAPI}+$ & 24 \\
\hline $28,492,516$ & 2017 & $\begin{array}{l}\text { ScreenCell } \\
\text { Cyto }\end{array}$ & 73 & 67 & IV & Squamous/ Adenocarcinoma & $>6 / 3 \mathrm{~mL}$ & N.A. & 34 \\
\hline $28,474,575$ & 2017 & Cellsearch & 107 & 65 & III/IV & NSCLC & $\geq 5 / 7.5 \mathrm{~mL}$ & CK+/CD45-/DAPI+, & 17 \\
\hline $28,289,866$ & 2017 & Cellsearch & 59 & 60 & III/IV & $\begin{array}{l}\text { Squamous/ Adenocarcinoma/ } \\
\text { Others }\end{array}$ & $\geq 2 / 7.5 \mathrm{~mL}$ & $\mathrm{CK}+/ \mathrm{CD} 45-/ \mathrm{DAPI}+$ & 24 \\
\hline $27,983,527$ & 2017 & Cellsearch & 100 & 62 & III/IV & Squamous Cancer & $\geq 5 / 7.5 \mathrm{~mL}$ & CK+/CD45-/DAPI+, & 9 \\
\hline $26,661,896$ & 2015 & $\begin{array}{l}\text { Cyttel } \\
\text { method }\end{array}$ & 46 & $(-)$ & III/IV & Squamous/ Adenocarcinoma & $\geq 8 / 3.2 \mathrm{~mL}$ & CD45- & 7 \\
\hline $21,422,424$ & 2010 & Cellsearch & 101 & 67 & III/IV & $\begin{array}{l}\text { Squamous/Poorly differentiated/ } \\
\text { Adenocarcinoma/Others }\end{array}$ & $\geq 5 / 7.5 \mathrm{~mL}$ & $\mathrm{CK}+/ \mathrm{CD} 45-/ \mathrm{DAPI}+$ & 9 \\
\hline $21,098,695$ & 2010 & ISET & 208 & 63 & $|/| I / I I / / V$ & $\begin{array}{l}\text { Squamous/ Adenocarcinoma/ } \\
\text { Large cell carcinoma/Sarcomatoid } \\
\text { carcinoma }\end{array}$ & $\geq 50 / 10 \mathrm{~mL}$ & N.A. & 64 \\
\hline
\end{tabular}

Note:

N.A: Not addressed

result showed that the $P$ values of PFS and OS were 0.221 and 0.659 respectively,indicating the publication bias was not remarkbale (Fig. $2 \mathrm{a}$ and b).

\section{Higher abundance of CTCs predicts shorter PFS of lung cancer cases}

Randomized model analyzing multivariate Cox Proportional Hazards Regression indicated that higher abundance of CTCs significantly predicts shorter PFS of lung cancer cases $(Z=2.31, P=0.02)$, however, heterogeneity among the studies was also considered to be remarkable $\left(\chi^{2}=79.07, P<0.00001 ; I^{2}=90 \%\right) \quad$ (Fig. 3a). Further stratified studies indicated the differences of heterogeneity among tumor stages were quite small $\left(\mathrm{I}^{2}=\right.$ $0 \%$ ) (Fig. 3b). Intriguingly, the abovementioned differences among various methods to detect CTCs were moderate $\left(\mathrm{I}^{2}=36.1 \%\right.$ ) (Fig. $\left.3 \mathrm{c}\right)$, potentially leading to the abovementioned heterogeneity in Fig. 3a.

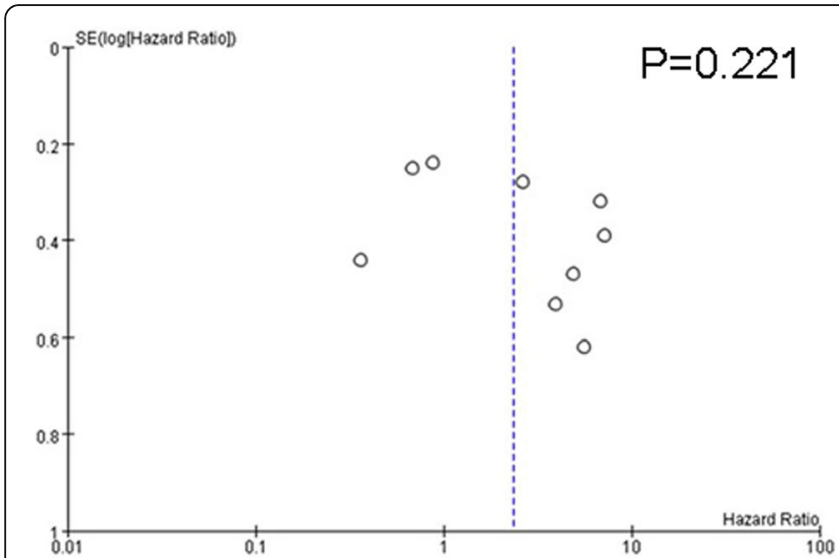

A

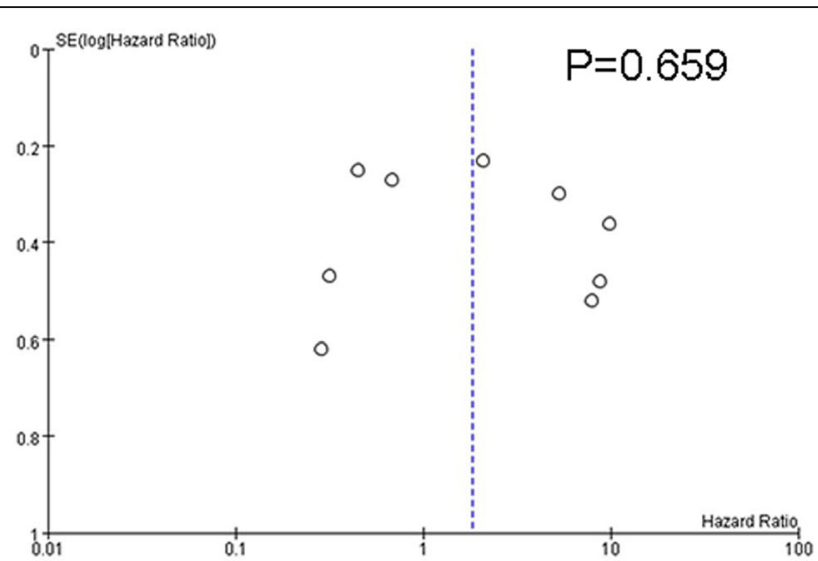

B

Fig. 2 Funnel plot verifies publication bias of studies. It unveiled that most studies are at the top of the inverted funnel, while there are few studies at the base, and the left and right are roughly symmetrical, so the publication bias is not obvious. a Funnel plot of studies focusing on PFS, $p=0.221$. b Funnel plot of studies focusing on OS, $p=0.659$ 


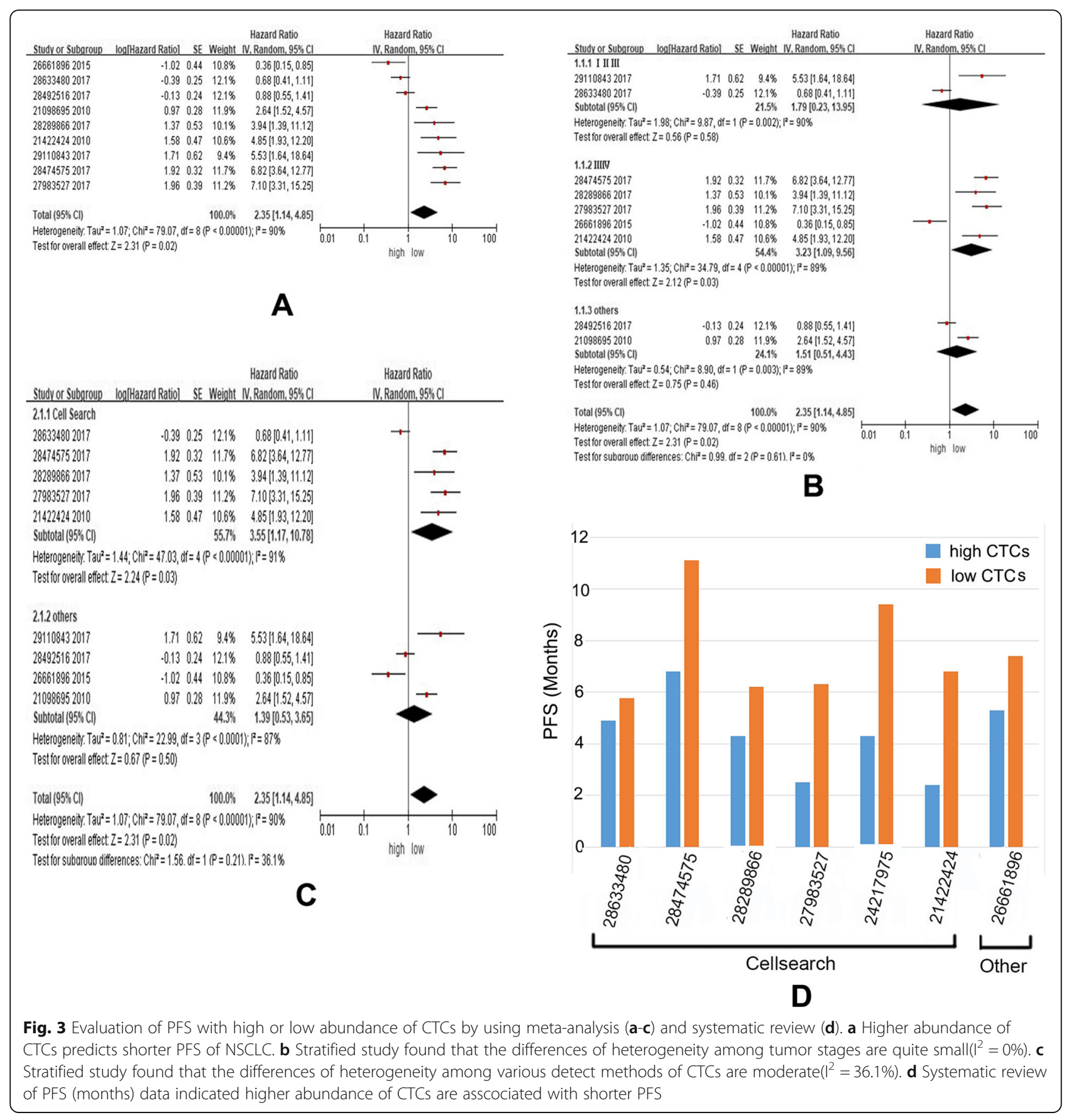

Systematic study of current available data of PFS (months) also indicated higher abundance of CTCs appeared in the cases with shorter PFS (Fig. 3d).

\section{Higher abundance of CTCs predicts shorter OS of advanced lung cancer cases}

Randomized model analyzing multivariate Cox Proportional Hazards Regression indicated that abundance of CTCs had no significant predictive power in total cohort mixing later and early stages $(\mathrm{Z}=1.36, P=0.17)$,however, heterogeneity test suggested significant heterogeneity among studies $\left(X^{2}=120.29, P<0.00001 ; \mathrm{I} 2=93 \%\right)$ (Fig. $4 \mathrm{a}$ ). Stratified analysis showed the differences of tumor stages in different cohorts lead to the abovementioned heterogeneity $\left(\mathrm{I}^{2}=81.5 \%\right)$, and higher abundance of CTCs seemed to had significant predict power in advanced cases $(\mathrm{Z}=2.44, P=0.01)$ (Fig. $4 \mathrm{~b})$. Intriguingly, various detect methods also could result in 


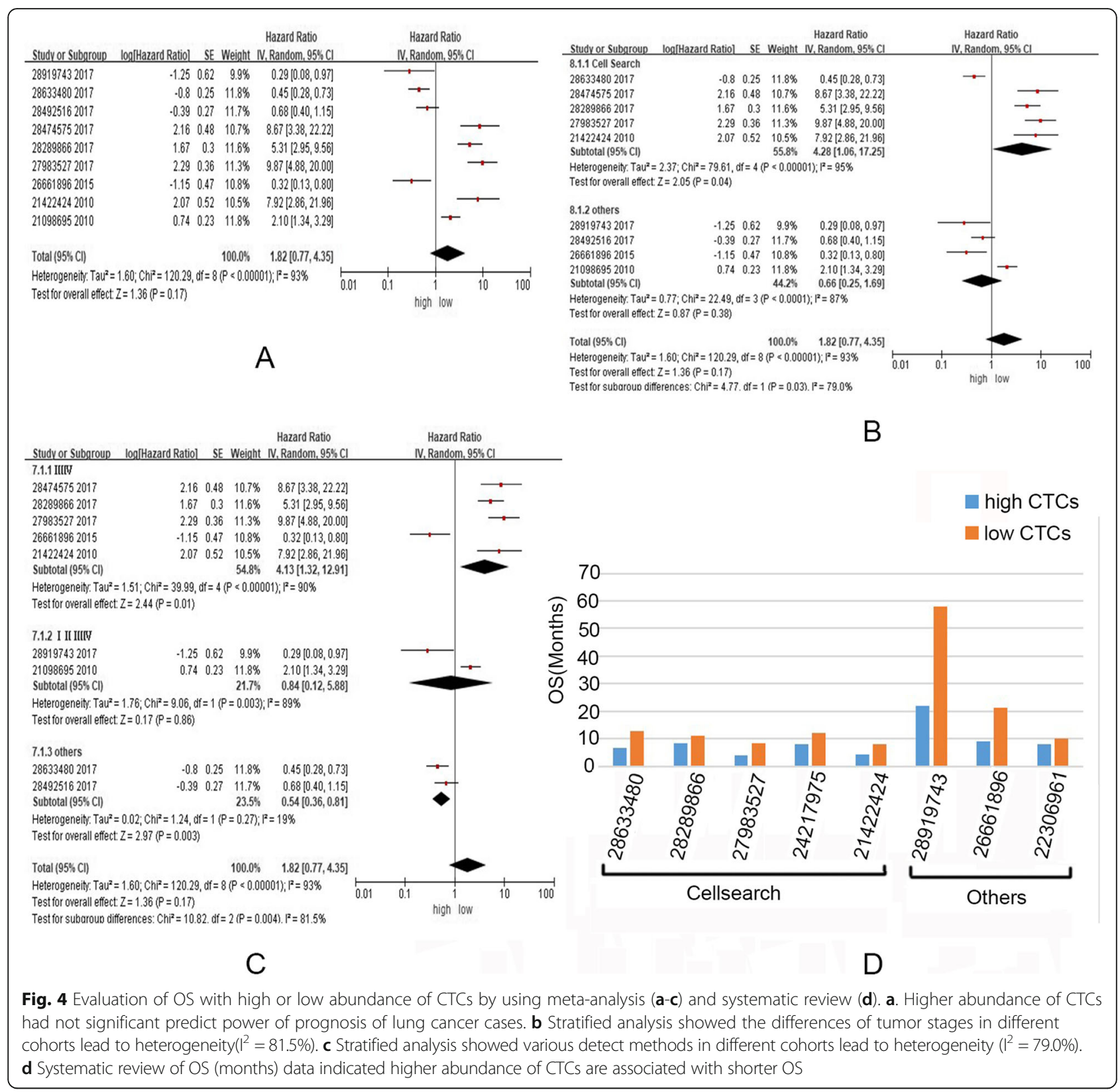

heterogeneity $\left(\mathrm{I}^{2}=79.0 \%\right)$. Indeed, we focused on the only studies by using CellSearch, and found the CTCs had more significant predicted power (Fig. 4c).

Systematic study of current data of OS (months) also indicated higher abundance of CTCs appeared in the cases with shorter OS (Fig. 4d).

\section{Discussion}

The appearance of CTCs in peripheral blood is often thought to be critical to remote tumor metastasis. Therefore, CTCs detection is considered to be an effective and non-invasive method that can be applied to diagnosis, and evaluation of treatment response, prognosis and recurrence risk of a variety of malignant tumors [9-11]. Thus far, various methods, e.g., CellSearch, High-gradient magnetic cell sorting (MACS), isolation by size of epithelial tumor cells (ISET), RT-PCR, Ficoll, OncoQuick and CTC-chip for detecting CTCs has been introduced. The abovementioned technologies for CTCs detection can be divided into EpCAM-based, e.g., CellSearch, MACS and CTC-chip or EpCAM-independent methods, e.g., ISET, RT-PCR, Ficoll and OncoQuick respectively.

CellSearch platform was the only method approved by the United States food and drug Administration (FDA) and commercially used for CTCs detection, which was designed to enrich CTCs basing on epithelial cell 
adhesion molecule (EpCAM). EpCAM-positive cells are enriched by immunomagnetic separation using EpCAMspecific antibodies conjugated to magnetic particles and then stained with fluorescent anti-cytokeratin and 40, 6diamino-2-phenylindole (DAPI), while hematopoietic cells are stained with anti-CD45 antibodies [12]. Thereafter, Semiautomated fluorescent microscope can be used to verify and count Cytokeratin(+)-DAPI (+)-CD45(-) CTCs [13]. Whilst EpCAM is expressed in the majority of CTCs, EMT can downregulate epithelial biomarkers including EpCAM, leading to the miss of a subpopulation of CTCs during enrichment or detection [14]. Furthermore, the specificity of CellSearch was also proved to be poor in normal individuals and in patients with benign tumors $[15,16]$.

MACS was designed to magnetically specifically label CTCs with an EpCAM, anti-cytokeratin 8 monoclonal antibody (mAb) which was directly conjugated to the superparamagnetic microbeads [17]. Magnetic beads targeting the tumor-specific cell antigen human epidermal growth factor receptor 2 (HER2) are also available [18]. Thereafter, CTCs are detected in the enriched cell fraction by flow cytometry, fluorescence microscopy, or immunocytochemistry [19]. This technique can highly deplete leukocytes and guarantee an efficient enrichment of tumor cells. As Cell search, EpCAM (-) CTCs cannot be detected by MACS.

ISET allows the counting and immunomorphological and molecular characterization of CTCs which are isolated and collected by filtration via an $8 \mu \mathrm{m}$-pores filtering membrane, due to larger size of tumor cells as compared with peripheral blood leukocytes [20]. Enriched cells are stained on the filter for cytomorphological, immunocytochemical or further examination [21]. While this method is convenient and economic, it lacks specificity because smaller tumor cells may be filtrated and ignored, or larger blood cells may be mistakenly collected and determined as tumor cells [22].

Ficoll density gradient centrifugation method is also based on cell morphology. In density centrifugation systems, erythrocytes, platelets, and polymorph nuclear cells are separated in the pellet, while mononuclear cells (MNCs), including CTCs, are collected in the so-called interphase which can be used for the further detection of tumor cells by immunocytochemistry or RT-PCR [23]. This method is relatively convenient and economic for all tumor types, but has poor specificity and low purification of isolated cells [9]. OncoQuick system, using multi-empty partitions to enrich tumor cells, was developed to satisfactorily reduce the co-enriched MNCs, with a high tumor cell recovery rate, and increase the chance of detecting CTCs [24].

Detection of mRNA that are overexpressed or mutated in cancer using RT-PCR is a more widely used as alternative. As RNA disappears quickly after cell death, detection of RNA is likely due to the presence of a whole tumor cell, not cell fragments or free RNA [25]. Theoretically, the sensitivity of RT-PCR is higher than immunocytochemistry, and false-positivity of RT-PCR is relatively high due to sample contamination, expression of target genes in normal cells, and pseudo genes. Collectively, RTPCR with it's higher sensitivity and lower specificity, as background noise due to expression of markers in normal cells, is hard to distinguish from a true positive signal [26]. Expectedly, optimization of combination of multi-markers assay may increase the accuracy of RT-PCR as adjuvant diagnosis method of lung cancer [27].

Recently, a novel method, i.e., CTC-chip is developed to detect CTCs [28] This chip consists of 78,000 micro posts coating with EpCAM antibodies and binds EpCAM-positive cells to the microposts, while whole blood is pumped through the system. Thereafter, a camera is used to detect the trapped cells basing on their morphology, viability and other tumor markers, e.g., CKs $(+)$ and DAPI $(+)$ and CD45(-). CTC-chip can result in specific enrichment and visual confirmation of CTCs, but may miss EpCAM negative CTCs [29].

Totally, the sensitivities of EpCAM-based detection methods seemed to be significantly lower than EpCAMindependent detection methods [30] [31] [32] due to the down-regulation of EpCAM in cancer cells during epithelial-mesenchymal EMT process. Therefore, CanPatrol $^{\mathrm{m}}{ }^{\mathrm{m}}$ is currently developed to classify and detect CTCs, as per both EMT markers, i.e., epithelial biomarkers (EpCAM and cytokeratins) and mesenchymal biomarkers (vimentin and twist) [33]. Therefore, CTCs can be clustered into three subtypes, i.e., CTCs with epithelial markers, CTCs with mesenchymal markers, and CTCs with both. Pilot study unveiled that detection of CTCs by using CanPatrol ${ }^{\text {Tw }}$ can effectively monitor tumor progression after operation in lung cancer cases [34]. Classifying CTCs by EMT markers helps to identify the more aggressive CTCs subpopulation. However, the discrimination and distinguishing of those biomarkers in CTCs as molecular prognostic factors warrants further robust study [35].

Detection of CTCs has been widely used for prediction of prognosis in a variety of malignancies, e.g., prostate cancer, breast cancer, neuroendocrine cancer and colorectal cancer. In patients with new metastatic hormone-sensitive prostate cancer, lower baseline CTCs (prior to treatment) were associated with higher rate of prostate-specific antigen (PSA) response [36]. The similar result was verified by another study on metastatic castration-resistant (which cannot be treated by excision) prostate cancer [37]. Another study on breast cancer confirmed the independent prognostic effect of CTC count on PFS and OS that higher CTC 
count prior to treatment was associated with decreased PFS and OS compared patients with lower CTC count [38]. Similarly, the presence of CTCs was associated with worse PFS and OS in neuroendocrine cancer patients [39]. Meanwhile, in patients with stage I and II colorectal cancer. CTC status was the only variable significantly associated with cancer relapse [40].

For meta-analysis, we only incorporated the data of multivariate, rather than univariate, Cox-regression model because multivariate model can adjust the influence of other prognostic factors, e.g., tumor stage and age, hence, it is more reliable. Our study revealed higher count of CTCs was associated with shorter PFS and OS of NSCLC. Furthermore, CTCs has higher predictive power for PFS as compared with OS, probably due to other demographical and clinical confounders, e.g., age, physical conditions, and compliance to the subsequent treatment after recurrence, which may influence OS. Intriguingly, stratified metaanalysis indicated that the predictive power of OS is more significant in stage III/IV patients than in other stage.

The heterogeneity among studies was significant $\left(\mathrm{I}^{2} \geq\right.$ $50 \%$ ), probably due to the differences of detection methods, cut off values, and pathological stages used in different studies. We tried to reduce the heterogeneity by stratifying the studies into subgroups according to the pathological stage and detection method in metaanalysis. Intriguingly, the heterogeneity was decreased remarkably, however, it still cannot be eliminated totally. For instance, the different cut-off values were used by the studies which used CellSearch which was approved by FDA for breast cancer without recommended cut-off value for lung cancer. Therefore, the studies took the different cut-off values referring to breast cancer or their own pilot study results. Additionally, we attempted to decrease the publication bias by searching studies completely, although no significant publication bias was found in the result of Egger's regression test. Inevitably, some drawer data will be missed.

\section{Conclusion}

High CTCs prior to initial treatment can predict shorter PFS and OS in NSCLC. It may provide an important evidence for precision and personalized therapy in lung cancer, for instance, the cases with higher level of CTCs prior to initial treatment or without satisfactory decrease trend of CTCs following treatment are supposed to undergo more fierce treatment. Furthermore, the efficient detection methods of CTCs with high sensitivity and specificity are required to be explored, and further robust clinical studies are warranted focusing on CTCs as prognostic factor of NSCLC patients.

\section{Abbreviations}

CTC: Circulating tumor cell; NSCLC: Non-small cell lung cancer

\section{Acknowledgements}

We'd appreciated Laura Muinelo and Giulia Stella for valuable comments which improves our manuscript greatly.

\section{Authors' contributions}

BD conceived and designed the study. SSJ and BD searched the data and performed data analysis. SSJ wrote the paper. BD, YGF, KQ, QYT and RWW reviewed and edited the manuscript. All authors read and approved the manuscript.

\section{Funding}

This study was supported by grants from the National Natural Science Foundations of China (NSFC) (No. 81572285), and National Natural Science Foundation of Chongqing City (No. cstc2018jcyjAX0592). We used the grants to get license of computer software for statistical analysis and access to publications which are not open access.

\section{Availability of data and materials}

The dataset was searched on PubMed (http://www.ncbi.nlm.nih.gov), EMBASE (https://www.embase.com/), Cochrane Library (https://www. cochranelibrary.com/). The search strategies and yielded citations were shown in Tables 1 and Fig. 1, respectively.

Ethics approval and consent to participate

Not applicable.

\section{Consent for publication}

Not applicable.

\section{Competing interests}

The authors declare that they have no competing interests.

Received: 10 April 2019 Accepted: 12 December 2019

Published online: 26 December 2019

\section{References}

1. Wong KHK, Tessier SN, Miyamoto DT, Miller KL, Bookstaver LD, Carey TR, et al. Whole blood stabilization for the microfluidic isolation and molecular characterization of circulating tumor cells. Nat Commun. 2017:8:1733.

2. Kou R, Zhao J, Gogoi P, Carskadon S, Chow W, Hwang C, et al. Enrichment and mutation detection of circulating tumor cells from blood samples. Oncol Rep. 2018;39:2537-44.

3. Liu DG, Xue L, Li J, Yang Q, Peng JZ. Epithelial-mesenchymal transition and GALC expression of circulating tumor cells indicate metastasis and poor prognosis in non-small cell lung cancer. Cancer Biomark. 2018;22:417-26.

4. Yin LC, Luo ZC, Gao YX, Li Y, Peng Q, Gao Y. Twist expression in circulating hepatocellular carcinoma cells predicts metastasis and prognoses. Biomed Res Int. 2018:2018:3789613.

5. Aggarwal C, Wang X, Ranganathan A, Torigian D, Troxel A, Evans T, et al. Circulating tumor cells as a predictive biomarker in patients with small cell lung cancer undergoing chemotherapy. Lung Cancer. 2017;112:118-25.

6. Murlidhar V, Reddy RM, Fouladdel S, Zhao L, Ishikawa MK, Grabauskiene S, et al. Poor prognosis indicated by venous circulating tumor cell clusters in early-stage lung cancers. Cancer Res. 2017;77:5194-206.

7. Coco S, Alama A, Vanni I, Fontana V, Genova C, Dal Bello MG, et al. Circulating Cell-Free DNA and Circulating Tumor Cells as Prognostic and Predictive Biomarkers in Advanced Non-Small Cell Lung Cancer PatientsTreated with First Line Chemotherapy Int J Mol Sci. 2017;18(5).

8. Jadad AR, Moore RA, Carroll D, Jenkinson C, Reynolds DJ, Gavaghan DJ, et al. Assessing the quality of reports of randomized clinical trials: is blinding necessary? Control Clin Trials. 1996;17:1-12.

9. Liu X, Zhang Z, Zhang B, Zheng Y, Zheng C, Liu B, et al. Circulating tumor cells detection in neuroblastoma patients by EpCAM-independent enrichment and immunostaining-fluorescence in situ hybridization. EBioMedicine. 2018:35:244-50.

10. Andriani F, Landoni E, Mensah M, Facchinetti F, Miceli R, Tagliabue E, et al. Diagnostic role of circulating extracellular matrix-related proteins in nonsmall cell lung cancer. BMC Cancer. 2018;18:899.

11. Zhou J, Dong F, Cui F, Xu R, Tang $X$. The role of circulating tumor cells in evaluation of prognosis and treatment response in advanced non-small-cell lung cancer. Cancer Chemother Pharmacol. 2017;79:825-33. 
12. Huebner H, Fasching PA, Gumbrecht W, Jud S, Rauh C, Matzas M, et al. Filtration based assessment of CTCs and CellSearch(R) based assessment are both powerful predictors of prognosis for metastatic breast cancer patients. BMC Cancer. 2018;18:204.

13. de Wit S, van Dalum G, Terstappen LW. Detection of circulating tumor cells. Scientifica (Cairo). 2014;2014:819362.

14. Lu J, Han B. Liquid biopsy promotes non-small cell lung Cancer precision therapy. Technology in cancer research \& treatment. 2018;17:1533033818801809.

15. Allard WJ, Matera J, Miller MC, Repollet M, Connelly MC, Rao C, et al. Tumor cells circulate in the peripheral blood of all major carcinomas but not in healthy subjects or patients with nonmalignant diseases. Clin Cancer Res. 2004;10:6897-904.

16. Hofman V, Bonnetaud C, Ilie MI, Vielh P, Vignaud JM, Flejou JF, et al. Preoperative circulating tumor cell detection using the isolation by size of epithelial tumor cell method for patients with lung cancer is a new prognostic biomarker. Clin Cancer Res. 2011;17:827-35.

17. Kwak B, Lee J, Lee J, Kim HS, Kang S, Lee Y. Spiral shape microfluidic channel for selective isolating of heterogenic circulating tumor cells. Biosens Bioelectron. 2018;101:311-6.

18. Zeune L, van Dalum G, Decraene C, Proudhon C, Fehm T, Neubauer H, et al. Quantifying HER-2 expression on circulating tumor cells by ACCEPT. PLOS One. 2017;12:e0186562.

19. Lin M, Liang SZ, Shi J, Niu LZ, Chen JB, Zhang MJ, et al. Circulating tumor cell as a biomarker for evaluating allogenic NK cell immunotherapy on stage IV non-small cell lung cancer. Immunol Lett. 2017;191:10-5.

20. Laget S, Broncy L, Hormigos K, Dhingra DM, BenMohamed F, Capiod T, et al. Technical insights into highly sensitive isolation and molecular characterization of fixed and live circulating tumor cells for early detection of tumor invasion. PLoS One. 2017;12:e0169427.

21. Sun N, Li X, Wang Z, Li Y, Pei R. High-purity capture of CTCs based on micro-beads enhanced isolation by size of epithelial tumor cells (ISET) method. Biosens Bioelectron. 2018;102:157-63.

22. Marrugo-Ramirez J, Mir M, Samitier J. Blood-based Cancer biomarkers in liquid biopsy: a promising non-invasive alternative to tissue biopsy. Int J Mol Sci. 2018;19:2877.

23. Kohli M, Ho Y, Hillman DW, Van Etten JL, Henzler C, Yang R, et al. Androgen receptor variant AR-V9 is Coexpressed with AR-V7 in prostate Cancer metastases and predicts Abiraterone resistance. Clin Cancer Res. 2017;23:4704-15.

24. Yang B, Qin A, Zhang K, Ren H, Liu S, Liu X, et al. Circulating tumor cells predict prognosis following tyrosine kinase inhibitor treatment in EGFRmutant non-small cell lung Cancer patients. Oncol Res. 2017;25:1601-6.

25. Qattan A, Intabli H, Alkhayal W, Eltabache C, Tweigieri T, Amer SB. Robust expression of tumor suppressor miRNA's let-7 and miR-195 detected in plasma of Saudi female breast cancer patients. BMC Cancer. 2017;17:799.

26. George JT, Jolly MK, Xu S, Somarelli JA, Levine H. Survival outcomes in Cancer patients predicted by a partial EMT gene expression scoring metric. Cancer Res. 2017;77:6415-28.

27. Deng CJ, Dai FQ, Qian K, Tan QY, Wang RW, Deng B, et al. Clinical updates of approaches for biopsy of pulmonary lesions based on systematic review. BMC pulmonary medicine. 2018;18:146.

28. Jiang W, Wang $H$, Cui $Y$, Lei $Y$, Wang $Y, X u$ D, et al. Polymer nanofiber-based microchips for EGFR mutation analysis of circulating tumor cells in lung adenocarcinoma. Int J Nanomedicine. 2018;13:1633-42.

29. Wu X, Xiao T, Luo Z, He R, Cao Y, Guo Z, et al. A micro-/nano-chip and quantum dots-based 3D cytosensor for quantitative analysis of circulating tumor cells. Journal of nanobiotechnology. 2018;16:65.

30. Krebs MG, Sloane R, Priest L, Lancashire L, Hou JM, Greystoke A, et al. Evaluation and prognostic significance of circulating tumor cells in patients with non-small-cell lung cancer. J Clin Oncol. 2011;29:1556-63.

31. Marchetti A, Del Grammastro M, Felicioni L, Malatesta S, Filice G, Centi I, et al. Assessment of EGFR mutations in circulating tumor cell preparations from NSCLC patients by next generation sequencing: toward a real-time liquid biopsy for treatment. PLoS One. 2014;9:e103883.

32. Hofman V, llie MI, Long E, Selva E, Bonnetaud C, Molina T, et al. Detection of circulating tumor cells as a prognostic factor in patients undergoing radical surgery for non-small-cell lung carcinoma: comparison of the efficacy of the CellSearch Assay and the isolation by size of epithelial tumor cell method. Int J Cancer. 2011;129:1651-60.
33. Wu S, Liu S, Liu Z, Huang J, Pu X, Li J, et al. Classification of circulating tumor cells by epithelial-mesenchymal transition markers. PLoS One. 2015; 10:e0123976.

34. Jin XR, Zhu LY, Qian K, Feng YG, Zhou JH, Wang RW, et al. Circulating tumor cells in early stage lung adenocarcinoma: a case series report and literature review. Oncotarget. 2017;8:23130-41.

35. Qi Y, Wang W. Clinical significance of circulating tumor cells in squamous cell lung cancer patients. Cancer Biomark. 2017;18:161-7.

36. Yu EY, Li H, Higano CS, Agarwal N, Pal SK, Alva A, et al. SWOG S0925: a randomized phase II study of androgen deprivation combined with Cixutumumab versus androgen deprivation alone in patients with new metastatic hormone-sensitive prostate Cancer. J Clin Oncol. 2015;33:1601-8.

37. Goldkorn A, Ely B, Quinn DI, Tangen CM, Fink LM, Xu T, et al. Circulating tumor cell counts are prognostic of overall survival in SWOG S0421: a phase III trial of docetaxel with or without atrasentan for metastatic castrationresistant prostate cancer. J Clin Oncol. 2014;32:1136-42.

38. Bidard FC, Peeters DJ, Fehm T, Nole F, Gisbert-Criado R, Mavroudis D, et al. Clinical validity of circulating tumour cells in patients with metastatic breast cancer: a pooled analysis of individual patient data. The Lancet Oncology. 2014;15:406-14.

39. Khan MS, Kirkwood A, Tsigani T, Garcia-Hernandez J, Hartley JA, Caplin ME, et al. Circulating tumor cells as prognostic markers in neuroendocrine tumors. J Clin Oncol. 2013;31:365-72.

40. Mescoli C, Albertoni L, Pucciarelli S, Giacomelli L, Russo VM, Fassan M, et al. Isolated tumor cells in regional lymph nodes as relapse predictors in stage I and II colorectal cancer. J Clin Oncol. 2012;30:965-71.

\section{Publisher's Note}

Springer Nature remains neutral with regard to jurisdictional claims in published maps and institutional affiliations.

Ready to submit your research? Choose BMC and benefit from:

- fast, convenient online submission

- thorough peer review by experienced researchers in your field

- rapid publication on acceptance

- support for research data, including large and complex data types

- gold Open Access which fosters wider collaboration and increased citations

- maximum visibility for your research: over $100 \mathrm{M}$ website views per year

At $\mathrm{BMC}$, research is always in progress.

Learn more biomedcentral.com/submissions 